\title{
Zinc fractionation in cow, goat, sheep and soybean milk samples using gel-electrophoresis and determination by electrothermal atomic absorption spectrometry (ETAAS)
}

Carla Maíra Bossu ${ }^{1,2+} \bullet$, Rodrigo Giglioti ${ }^{3} \bullet$, Marcia Cristina de Sena Oliveira ${ }^{1} \bullet$, Pedro Vitoriano de Oliveira ${ }^{4} \bullet$, Ana Rita de Araujo Nogueira ${ }^{1} \bullet$

1.Embrapa Pecuária Sudeste, São Carlos, São Paulo, Brazil

2.Federal University of São Carlos, Chemical Department, São Carlos, São Paulo, Brazil

3.Zootechnics Institute of the São Paulo State Government, Nova Odessa, São Paulo, Brazil

4.University of São Paulo, Institute of Chemistry, Department of Fundamental Chemistry, São Paulo, São Paulo, Brazil

+Corresponding author: Carla Maíra Bossu, Phone: +55 16 3411-5724, Email address: carla.bossu@gmail.com

$\begin{array}{ll}\text { ARTICLE INFO } & \text { Keywords } \\ & \text { 1. zinc } \\ \text { Article history: } & \text { 2. milk } \\ \text { Received: October } 07,2019 & \text { 3. proteins } \\ \text { Accepted: June } 02,2020 & \text { 4. fractionation } \\ \text { Published: January 01, } 2021 & \end{array}$

\begin{abstract}
A screening method for zinc levels in different milk samples (raw cow, raw sheep, UHT cow, UHT goat and soybean milk base) was performed to establish the $\mathrm{Zn}$ levels' differences in protein samples. The samples were digested in a cavity microwave oven and the total $\mathrm{Zn}$ levels in the extracts were determined by flame absorption atomic spectrometry (FAAS). The protein separation was performed by urea polyacrylamide gel electrophoresis (UREA-PAGE). Protein bands were digested in the cavity microwave oven and $\mathrm{Zn}$-protein analysis was further conducted by electrothermal atomic absorption spectrometry (ETAAS). The results showed that $\mathrm{Zn}$ is mainly bound to $32 \mathrm{kDa}$ ( $\beta$-casein) protein $(17.0 \pm 2.0 \%)$ in UHT cow and $24 \mathrm{kDa}(\alpha$-casein) protein $(9.0 \pm 0.6 \%)$ in raw sheep milk. This method provided quantitative information regarding $\mathrm{Zn}$ species present in the protein fractions of the milk samples. The accuracy was evaluated using certified reference material (whole milk powder, NIST 8435) with statistically equivalent concentrations (Student's $t$-test) for total $\mathrm{Zn}$ and by addition and recovery experiments applied to measure $\mathrm{Zn}$-protein. The recovered values were in the $92-110 \%$ range.
\end{abstract}




\section{Introduction}

Zinc (Zn) is a trace element essential in human and animal nutrition and participates in critical biological processes, such as the synthesis and degradation of carbohydrates, lipids, proteins and nucleic acids. It is present in food in two forms: bound with organic molecules and in inorganic salts ${ }^{1}$. Milk is one of the main sources of zinc in the human diet, responsible for about $25 \%$ of the total recommended daily intake of this metal ${ }^{1,2}$. Milk is a complete source of nutrients, containing minerals, vitamins, carbohydrates, lipids, water and proteins, which are especially crucial for newborns' growth and development ${ }^{3}$.

As humans continue to consume milk during childhood and adulthood, highlighting the expressive consumption of cow's milk, it is essential to understand better the chemical composition of milk, including the mineral levels and their physiological influence on human and animal nutrition, as well as trace elements toxicity ${ }^{2}$.

Studies about different chromatographic methods have indicated differences in the association between $\mathrm{Zn}$ and proteins in human and cow's milk. In cow's milk, the complex $\mathrm{Zn}$-casein-Ca-P is the predominant form, while in human milk, Zn-citrate species seem to be predominant ${ }^{4}$. In the environmental, biological, medical and biochemical research areas, studies about metal-protein interaction are necessary to improve the knowledge about the toxicity, bioavailability, transport and physicochemical properties of an element ${ }^{5}$.

Nutrient fractionation in food is necessary to understand availability and absorption prediction. Fractionation is defined as the classification process of an analyte or an analyte group in a specific sample according to physical (e.g., size, solubility) or chemical (e.g., bonding, reactivity) properties ${ }^{6}$. One relatively simple procedure to fractionate proteins from food samples is the polyacrylamide gel electrophoresis, which shows high selectivity and consists in the separation of molecules loaded in a particular way under the influence of an electric potential difference ${ }^{7}$. One of the main uses of the gel electrophoresis technique containing urea is the characterization of proteins in various types of milk ${ }^{8}$.

Studies about metal-protein interaction using polyacrylamide gel electrophoresis, followed by different analytical techniques for metals determination, have been developed for several kinds of application ${ }^{9-16}$. These works belong to an important field of science called metallomic, which has allowed for the integration of analytical studies with inorganic and biochemical studies. Therefore, there is a growing demand for accurate and selective procedures that allow the quantification and speciation of trace elements, especially in foods, to obtain relevant information about metal-protein binding, which is intimately related to the nutrients bioavailability ${ }^{7,17}$.

In this context, the present work aimed at investigating the separation of proteins in different kinds of milk samples, by urea polyacrylamide gel electrophoresis (UREA-PAGE), and to establish Zn(II) concentrations in each protein determined by electrothermal atomic absorption spectrometry (ETAAS). The $\mathrm{Zn}$ distribution results in protein bands were quantitative and provided information about $\mathrm{Zn}$ levels present in the milk samples' protein fractions.

\section{Experimental}

\subsection{Instrumentation}

A Varian model SpectrAA-800 graphite furnace atomic absorption spectrometer (Mulgrave, Victoria, Australia) equipped with a graphite furnace atomizer, GTA 100 autosampler, was used for zinc quantification in the proteins bands. Background correction by Zeeman-effect was employed to correct for nonspecific absorbance. Pyrocoated graphite tubes (Part Number 63-100011-00, Varian) furnace with longitudinal heating was throughout. All signals were measured as integrated absorbance. A zinc hollow cathode lamp $(\lambda=213.9 \mathrm{~nm}$, slit $=1.0 \mathrm{~nm})$ operating in $5 \mathrm{~mA}$ was employed as radiation source. Argon 99.998\% (Air liquid Sao Paulo, Brazil) was used as purge gas. The heating programs used after the optimization of pyrolysis and atomization temperatures are shown in Tab. 1.

The total $\mathrm{Zn}$ was carried out using a flame atomic absorption spectrometer (model SpectrAA 250 plus, Varian, Mulgrave, Australia) equipped with a Zn hollow cathode lamp $(\lambda=213.9 \mathrm{~nm}$, slit $=1.0 \mathrm{~nm})$ and $5 \mathrm{~mA}$ lamp current were employed as primary radiation sources. Air/acetylene flame was used at $13.4 \mathrm{~L} \mathrm{~min}^{-1}$ and $2 \mathrm{~L} \mathrm{~min}^{-1}$ air and acetylene flows, respectively.

The Mini-gel (Vertical Electrophoresis System Mini, BioAmerica Inc. Equipments, Miami, USA) with $8.5 \mathrm{~cm}$ (height) $\mathrm{x} 10.0 \mathrm{~cm}$ (width) and a centrifuge (5417R, Eppendorf, Hamburg, Germany) were used for gel-electrophoresis.

The milk samples were microwave digested assisted (Multiwave, Anton Paar, Graz, Austria) with $50 \mathrm{~mL}$ PFA vessels. The total protein amount was determined by spectrophotometry (Spectrophotometer model 432, Femto, Sao Paulo, Brazil). 
Table 1. GF AAS heating program used in the zinc protein bands.

\begin{tabular}{|l|c|c|c|c|}
\hline \multicolumn{1}{|c|}{ Step } & Temperature $/{ }^{\circ} \mathbf{C}$ & Hold Time $/ \mathbf{s}$ & Ar Flow / L min $^{-1}$ & Reading \\
\hline Drying & 85 & 2.0 & 3.0 & No \\
\hline Drying & 95 & 8.0 & 3.0 & No \\
\hline Drying & 120 & 10 & 3.0 & No \\
\hline Pyrolysis & 1000 & 5.0 & 3.0 & No \\
\hline Pyrolysis & 1000 & 1.5 & 3.0 & No \\
\hline Atomization & 1600 & 0.8 & 0 & Yes \\
\hline Atomization & 1600 & 2.9 & 0 & Yes \\
\hline Cleaning & 2500 & 2.9 & 3.0 & No \\
\hline
\end{tabular}

\subsection{Reagents and materials}

All solutions were prepared using deionized water (resistivity $>18.2 \mathrm{M} \Omega \mathrm{cm}$ ) obtained from a Milli-Q water purification system (Millipore, Bedford, MA, USA). Nitric acid $\left(\mathrm{HNO}_{3}\right)$ (Synth, Diadema, SP, Brazil) previously purified using a sub-boiling distillation system (Milestone, Sorisole, Italy), and hydrogen peroxide $\left(\mathrm{H}_{2} \mathrm{O}_{2}\right) 30 \% \mathrm{w} \mathrm{v}^{-1}$ (Sigma Aldrich, Switzerland) were used to digest the samples.

A solution of $1.78 \%(\mathrm{~m} / \mathrm{v}) \mathrm{Mg}\left(\mathrm{NO}_{3}\right)_{2}$ (Merck, Darmstadt, Germany) was used as a chemical modifier. Analytical reference solutions between 0.2 and $1.0 \mathrm{mg}$ $\mathrm{L}^{-1}$ of $\mathrm{Zn}$ were prepared by successive dilutions of a stock solution containing $1000 \mathrm{mg} \mathrm{L}^{-1} \mathrm{Zn}$ (Tec-Lab, Hexis, Jundiai, SP, Brazil).

The analytical curve for $\mathrm{Zn}$ determination in protein bands was obtained using analytical solutions with concentrations between 0.5 and $3.0 \mu \mathrm{g} \mathrm{L}^{-1} \mathrm{Zn}$ in blank gel band previously microwave-assisted digested with $\mathrm{HNO}_{3} 1.0 \%(\mathrm{v} / \mathrm{v})$.

\subsection{Samples}

Fresh milk samples from Holstein cows aged between 3 to 4 years, weighing an average of $450 \mathrm{~kg}$ and raised in a semi-intensive system, and sheep from Santa Inês were collected at the Embrapa Pecuária Sudeste, located in São Carlos, SP, Brazil. Samples of ultra-high temperature (UHT) cow milk, UHT goat milk and soybean milk base were purchased in the local market of São Carlos, SP, Brazil. Samples were stored in a fridge at $-4{ }^{\circ} \mathrm{C}$ before analysis.

Certified reference milk sample (NIST 8435 Whole Milk Powder) from the National Institute of Science and Technology (NIST, Gaithersburg, MD, USA) was used to check the methods' accuracy for the measurement of total $\mathrm{Zn}$. Addition and recovery experiments were performed to evaluate the species of $\mathrm{Zn}$.

\subsection{Procedures}

\subsubsection{Evaluation of pyrolysis and atomization temperature}

The pyrolysis and atomization temperature curves were constructed with $18 \mu \mathrm{L}$ of the standard or sample solutions in the presence of a chemical modifier, $5 \mu \mathrm{L}$ of $\mathrm{Mg}\left(\mathrm{NO}_{3}\right)_{2} \quad 1.78 \%$ (w/v). The temperatures were evaluated in a range of $700-1800{ }^{\circ} \mathrm{C}$ using increments of $100{ }^{\circ} \mathrm{C}$. Solutions of $1.0 \mu \mathrm{g} \mathrm{L}^{-1} \mathrm{Zn}$ were prepared for this evaluation using the blank sample, a piece of polyacrylamide gel without protein band, in acid digested $\left(\mathrm{HNO}_{3} 1.0 \% \mathrm{v} / \mathrm{v}\right)$.

\subsubsection{Sample preparation for total $\mathrm{Zn}$ and species determination}

Zinc's total mass fractions were determined in the milk samples using a microwave-assisted acid digestion. In brief, $2.5 \mathrm{~mL}$ of milk samples or $250 \mathrm{mg}$ of the certified reference material was directly weighted in the microwave vessel. Then, $1.0 \mathrm{~mL}$ of $\mathrm{H}_{2} \mathrm{O}_{2} 30 \%(\mathrm{w} / \mathrm{v}), 1 \mathrm{~mL}$ of $\mathrm{H}_{2} \mathrm{O}$ and $1.0 \mathrm{~mL}$ of $\mathrm{HNO}_{3}$ $65 \%(\mathrm{v} / \mathrm{v})$ were added and the mixture submitted to the following microwave heating program: $5 \mathrm{~min}$ from 0 to $100 \mathrm{~W}, 5 \mathrm{~min}$ at $600 \mathrm{~W}, 5 \mathrm{~min}$ at $1000 \mathrm{~W}$ followed by 15 min of cooling. After digestion and cooling, the digests were transferred to volumetric flasks and the volume was made up to $20 \mathrm{~mL}$ with deionized water.

Protein bands ( $8 \mathrm{~mm}$ wide by 3 to $5 \mathrm{~mm}$ in height) of the milk samples and the blank (gel region without the protein) obtained by electrophoresis were cut, washed with deionized water and dried on filter paper for $15 \mathrm{~min}$ in the laminar flow cabinet before weighting (each band was approximately $50 \mathrm{mg}$ ). The bands were placed in PTFE mini-bottles, and $75 \mu \mathrm{L}$ $65 \%(\mathrm{v} / \mathrm{v}) \mathrm{HNO}_{3}$ plus $75 \mu \mathrm{L} 30 \%(\mathrm{w} / \mathrm{v}) \mathrm{H}_{2} \mathrm{O}_{2}$ were added.

The mini bottles were placed into the microwave PFA vials containing $2 \mathrm{~mL}$ deionized water. Figure 1 
shows the container configuration used. The microwave heating program was run as follows: $1 \mathrm{~min}$ from 0 to $250 \mathrm{~W}, 1 \mathrm{~min}$ at $0 \mathrm{~W}, 5 \mathrm{~min}$ at $250 \mathrm{~W}, 5 \mathrm{~min}$ at $400 \mathrm{~W}, 10 \mathrm{~min}$ at $750 \mathrm{~W}$ followed by $10 \mathrm{~min}$ of cooling. After digestion and cooling, the digests were transferred to volumetric flasks and the volume was made up to $3.5 \mathrm{~mL}$ with deionized water.

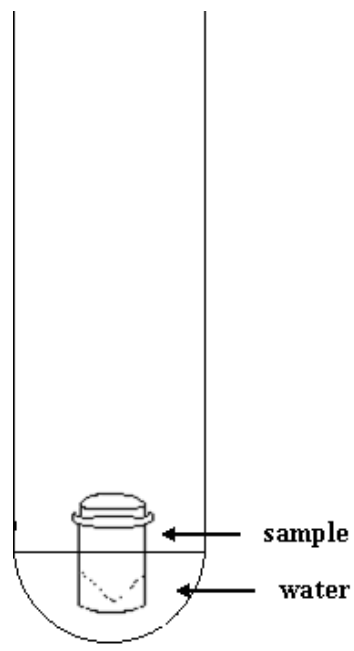

Figure 1. Sample container into the vial of the microwave cavity vessel.

\subsubsection{Gel Electrophoresis}

Urea-polyacrylamide gel electrophoresis (UREAPAGE) was carried out using a separation gel composed of acrylamide (4\% for stacking gel and $10 \%$ for separation gel), as described by Egito et al. ${ }^{18}$, with modifications.

The separation gel was composed of $2.25 \mathrm{~mL}$ acrylamide/Bis (40 g acrylamide (Invitrogen, USA) and $2 \mathrm{~g} \mathrm{~N}, \mathrm{~N}$-methylene bisacrylamide (BIS) (Sigma, Germany) in $100 \mathrm{~mL}$ solution) and $7.10 \mathrm{~mL}$ separation gel buffer (6.43 g of TRIS (Synth, SP, Brazil), $38.57 \mathrm{~g}$ urea (J.T. Baker, Germany), $0.572 \mathrm{~mL} \mathrm{HCl}$ (Aldrich Chemical, Milwaukee, WI, USA), with $\mathrm{pH}$ adjusted to 8.9 in $100 \mathrm{~mL}$ solution).

The stacking gel was prepared using $0.39 \mathrm{~mL}$ acrylamide/Bis and $3.52 \mathrm{~mL}$ stacking gel buffer $(0.830$ $\mathrm{g}$ TRIS, $30 \mathrm{~g}$ urea, $0.44 \mathrm{~mL} \mathrm{HCl}$, with $\mathrm{pH}$ adjusted to 7.6 in $100 \mathrm{~mL}$ solution). Both gels also contained N,N,N',N'-tetramethylethylenediamine (TEMED) (J.T. Baker, Germany) and $10 \%(\mathrm{~m} / \mathrm{v})$ ammonium persulfate (Sigma, Germany). Finally, Tris-glycine buffer solution (3.75 g TRIS and $18.25 \mathrm{~g}$ glycine (Sigma, Germany) in $250 \mathrm{~mL}$ of solution, diluted 5 times) was used in the reservoir.
To sample preparation, $30 \mu \mathrm{L}$ of samples and standard curve of purified protein markers (GE Healthcare) were dissolved in $1.0 \mathrm{~mL}$ of buffer solution, composed by $0.375 \mathrm{~g}$ TRIS, $24.5 \mathrm{~g}$ urea, 0.2 $\mathrm{mL} \mathrm{HCl}, 0.35 \mathrm{~mL} \beta$-mercaptoethanol (Inlab, Brazil) and $0.075 \mathrm{~g}$ bromophenol blue (Merck) diluted to 50 $\mathrm{mL}$ with water. After dissolution, the samples were immersed in a water bath at $40{ }^{\circ} \mathrm{C}$ for $1 \mathrm{~h}$ and centrifuged at $5{ }^{\circ} \mathrm{C}$ for $10 \mathrm{~min}$ at $10000 \times \mathrm{g}$. Then, 30 $\mu \mathrm{L}$ of supernatant was applied to a single slot. The initial and final currents were 23 and $24 \mathrm{~mA}$ and the voltage was set at $90 \mathrm{~V}$ for $4.5 \mathrm{~h}$. After the protein migration, protein bands were stained overnight with a solution containing $0.5 \mathrm{~g}$ of Coomassie brilliant blue G-250 (Sigma, Germany) and $3.75 \mathrm{~mL}$ of $\mathrm{H}_{2} \mathrm{SO}_{4}$ (Quemis, Brazil) in $500 \mathrm{~mL}$ solution. This solution was then filtered using filter paper and mixed to $55.6 \mathrm{~mL}$ of $10 \mathrm{~mol} \mathrm{~L}^{-1} \mathrm{KOH}$ and $66.67 \mathrm{~mL}$ of $12 \%(\mathrm{w} / \mathrm{v})$ trichloroacetic acid (Synth, Brazil). Finally, the gels were washed with deionized water and stored in $10 \%$ $(\mathrm{v} / \mathrm{v})$ glycerol $10 \% \quad(\mathrm{v} / \mathrm{v})$ methanol solution (Proquímios, Brazil).

The molecular weight proteins were estimated according to standard purified protein markers, including phosphorylase b $(97.0 \mathrm{kDa})$, albumin $(66.0$ $\mathrm{kDa})$, ovalbumin $(45.0 \mathrm{kDa})$, carbonic anhydrase $(30.0$ $\mathrm{kDa})$, trypsin inhibitor $(20.1 \mathrm{kDa})$ and $\alpha$-Lactalbumin $(14.4 \mathrm{kDa})$. The gel electrophoresis UREA-PAGE was performed in triplicate for each sample and separately to avoid contamination.

\subsubsection{Determination of Total Protein concentration}

The total protein concentration was determined through the Bradford method ${ }^{19}$ by adding $1.25 \mathrm{~mL}$ of the Bradford reagent (Coomassie Brilliant Blue G-250) and $100 \mu \mathrm{L}$ of bovine serum albumin (BSA) (Sigma, USA) standard solutions or the samples and measuring the absorbance after $5 \mathrm{~min}$ at $595 \mathrm{~nm}$, in triplicate. The analytical curve was constructed by using standard solutions of BSA at concentrations between 50 and 250

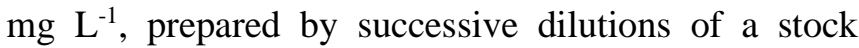
solution containing $1000 \mathrm{mg} \mathrm{L}^{-1}$ of BSA.

\section{Results and discussion}

\subsection{Gel Electrophoresis}

Figure 2 shows the gels electrophoresis obtained for each milk sample, where columns 2 to 6 correspond to the protein bands of each sample, and column 1 shows 
the low molecular weight (LMW) standard protein $(14.4$ to $97 \mathrm{kDa})$. The dashed rectangles represent the bands studied with the approximate molecular weight, as this is a qualitative analysis. The protein molecular mass values, found from top to bottom, were 52 and 39 $\mathrm{kDa}$ for the soybean milk base (column 2), 32 and 24 $\mathrm{kDa}$ for raw sheep (column 3), 32 and $24 \mathrm{kDa}$ for UHT cow (column 4), $32 \mathrm{kDa}$ for UHT goat (column 5) and 32 and $24 \mathrm{kDa}$ raw cow (column 6).

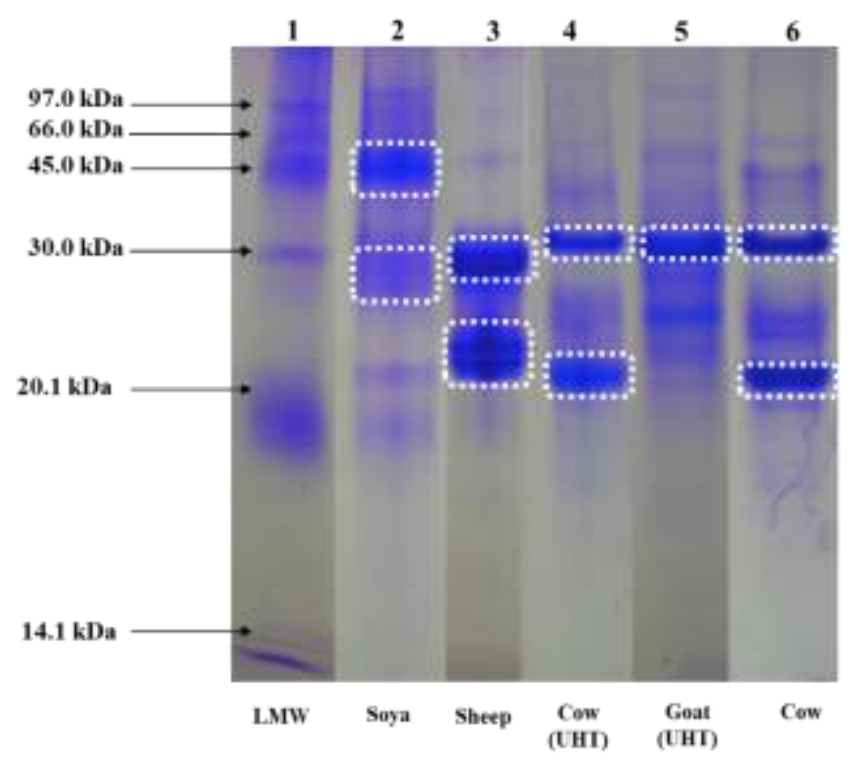

Figure 2. Zinc protein bands of milk samples run in polyacrylamide gel $(10 \%)$ with urea.

Casein is the major component of milk protein. In this work, $\alpha$-casein, $\beta$-casein and soybean proteins showed profiles similar to other studies ${ }^{18,20,21}$ with approximately $24 \mathrm{kDa}$ and $32 \mathrm{kDa}$ for $\alpha$-casein and $\beta$ casein, respectively. Bands of higher intensity for raw sheep, UHT cow, raw cow and UHT goat were in the molar mass range of $32 \mathrm{kDa}$. For the soybean milk base, the bands 52 and $39 \mathrm{kDa}$ were assigned to $\beta$ conglycine subunits and glycine, respectively ${ }^{20,22}$.

Naqvi et $a l .^{23}$ reported that it was also possible to observe that $\mathrm{Ca}, \mathrm{Fe}, \mathrm{Mg}$ and $\mathrm{Zn}$ were mainly associated with colloidal calcium phosphate in casein micelles. For soybeans, $80 \%$ of the extracted proteins are $\beta$ conglycine (7S) and glycine (11S). Denaturation by heating occurs when there are interactions between these proteins, which can form basic subunits, such as (11S), $\beta$-subunits (7S), and $\alpha$-, $\alpha^{\prime}$-subunits (7S $)^{20,22}$.

\subsection{Total $\mathrm{Zn}$ and species determination}

Among the micronutrients present in milk, $\mathrm{Zn}$ has the highest concentration and is important in human and animal nutrition, associated with organic molecules and present as inorganic salts. Concerning amino acids such as histidine and methionine and phosphates and organic acids, it enables the bioavailability of this element ${ }^{1}$. It is also associated with one of the most important milk proteins, casein, and in the bovine milk, $\mathrm{Zn}$ is present as $\mathrm{Zn}$-casein-Ca-P complex ${ }^{4}$.

The total zinc levels obtained in the samples are shown in Tab. 2 and agree with those reported in the literature $^{24,25}$. No significant difference (Student's $t$-test 95\% level, $\mathrm{p}>0.05$ ) was found between the certified reference material NIST $8435\left(28 \pm 3 \mathrm{mg} \mathrm{kg}^{-1}\right)$ and the measured value of certified reference material $(26 \pm 1$ $\mathrm{mg} \mathrm{kg}^{-1}$ ) for $\mathrm{Zn}$. Therefore, this study can confirm the accuracy of the procedure. The slope and correlation coefficient ( $\mathrm{r}$ ) of the FAAS calibration curve prepared in the presence of $1.0 \%(\mathrm{v} / \mathrm{v})$ of $\mathrm{HNO}_{3}$ were 0.4688 and 0.9994, respectively. Moreover, limits of detection (LOD) calculated as three times the standard deviation of the blank $(\mathrm{n}=10) /$ slope was $0.02 \mathrm{mg} \mathrm{L}^{-1}$ and quantification (LOQ) $\left(3 \times\right.$ LOD) was $0.03 \mathrm{mg} \mathrm{L}^{-1}$ for $\mathrm{Zn}$, which are appropriate for $\mathrm{Zn}$ determination in the evaluated milk samples ${ }^{26}$.

The pyrolysis and atomization temperature were evaluated to find the $\mathrm{Zn}$ measurement's best conditions in proteins by ETAAS (Fig. 3). The drying and cleaning temperatures were used according to Bossu et $a l^{27}$. Pyrolysis temperature was set at $1000{ }^{\circ} \mathrm{C}$ and the atomization temperature was set at $1600{ }^{\circ} \mathrm{C}$. In this condition, the absorbance analytical signals' best profiles and the smallest deviations between the measurements were observed. The coefficient of variation was around $3.0 \%(n=3)$ and the graphite furnace heating program used to $\mathrm{Zn}$ determination in the protein bands of different milk samples is shown in Tab. 1.

The slope and correlation coefficient (r) of ETAAS analytical curve in the presence of blank sample media (gel without protein) were 0.1457 and 0.995 , respectively. The method's accuracy was evaluated by the addition and recovery procedure. Recoveries of 110 $\pm 1 \%, 92 \pm 3 \%, 99 \pm 4 \%, 95 \pm 8 \%$ were obtained after adding $1.5 \mu \mathrm{g} \mathrm{L}^{-1}$ of $\mathrm{Zn}$ to proteins bands $32 \mathrm{kDa}$ UHT cow, $32 \mathrm{kDa}$ UHT goat, $39 \mathrm{kDa}$ soybean and $24 \mathrm{kDa}$ raw sheep, respectively. These recovery values are in the range established according to the quantified concentration level ${ }^{28,29}$. LOD and LOQ for $\mathrm{Zn}$ determination by ETAAS, using the optimized

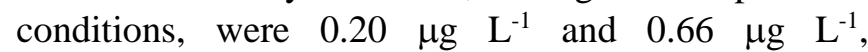
respectively.

The results for $\mathrm{Zn}$ distribution in protein bands were quantitative and provide information about the relative 
$\mathrm{Zn}$ concentration in each protein band from milk samples, as well as its relationship with the total levels of $\mathrm{Zn}$ found in milk samples (Tab. 2). Zinc is present predominantly in $32 \mathrm{kDa}$ protein in UHT cow milk, followed by $32 \mathrm{kDa}$ raw cow milk and $24 \mathrm{kDa}$ raw sheep milk, which showed similar Zn levels.

Table 2. Zinc mass fractions (\%) obtained for protein bands (Zn-protein) by ETAAS and Total Zinc (mg $\mathrm{L}^{-1}$ ) obtained for milk samples (ZnT) by FAAS, $\mathrm{n}=3$.

\begin{tabular}{|c|c|c|c|c|}
\hline \multicolumn{5}{|c|}{ Concentration/\% \pm standard uncertainty ${ }^{\mathrm{a}}$, Concentration $/ \mathrm{mg} \mathrm{L}^{-1} \pm$ standard uncertainty $^{\mathrm{b}}$ and coefficient of variation $(\mathrm{CV}) / \%$} \\
\hline Samples / kDa & Zn-protein / \% & $\mathrm{CV} / \%$ & Total Zinc / $\mathrm{mg} \mathrm{L}^{-1} \mathrm{~b}$ & $\mathrm{CV} / \%$ \\
\hline Soybean milk-based / 52 & n.d & n.d & \multirow{2}{*}{$2.50 \pm 0.07$} & \multirow{2}{*}{2.8} \\
\hline Soybean milk-based / 39 & $4.4 \pm 0.6$ & 12.6 & & \\
\hline UHT Cow / 32 & $17.0 \pm 2.0$ & 9.4 & \multirow{2}{*}{$3.20 \pm 0.02$} & \multirow{2}{*}{0.6} \\
\hline UHT Cow / 24 & $8.0 \pm 1.0$ & 17.6 & & \\
\hline UHT Goat / 32 & $5.2 \pm 0.9$ & 16.3 & $2.75 \pm 0.01$ & 0.4 \\
\hline Cow / 32 & $8.0 \pm 1.0$ & 8.3 & \multirow{2}{*}{$3.44 \pm 0.05$} & \multirow{2}{*}{1.5} \\
\hline Cow / 24 & n.d & n.d & & \\
\hline Sheep / 32 & $1.7 \pm 0.2$ & 9.7 & \multirow{2}{*}{$2.76 \pm 0.01$} & \multirow{2}{*}{0.4} \\
\hline Sheep / 24 & $9.0 \pm 0.6$ & 6.8 & & \\
\hline
\end{tabular}

n.d $=$ not detected.

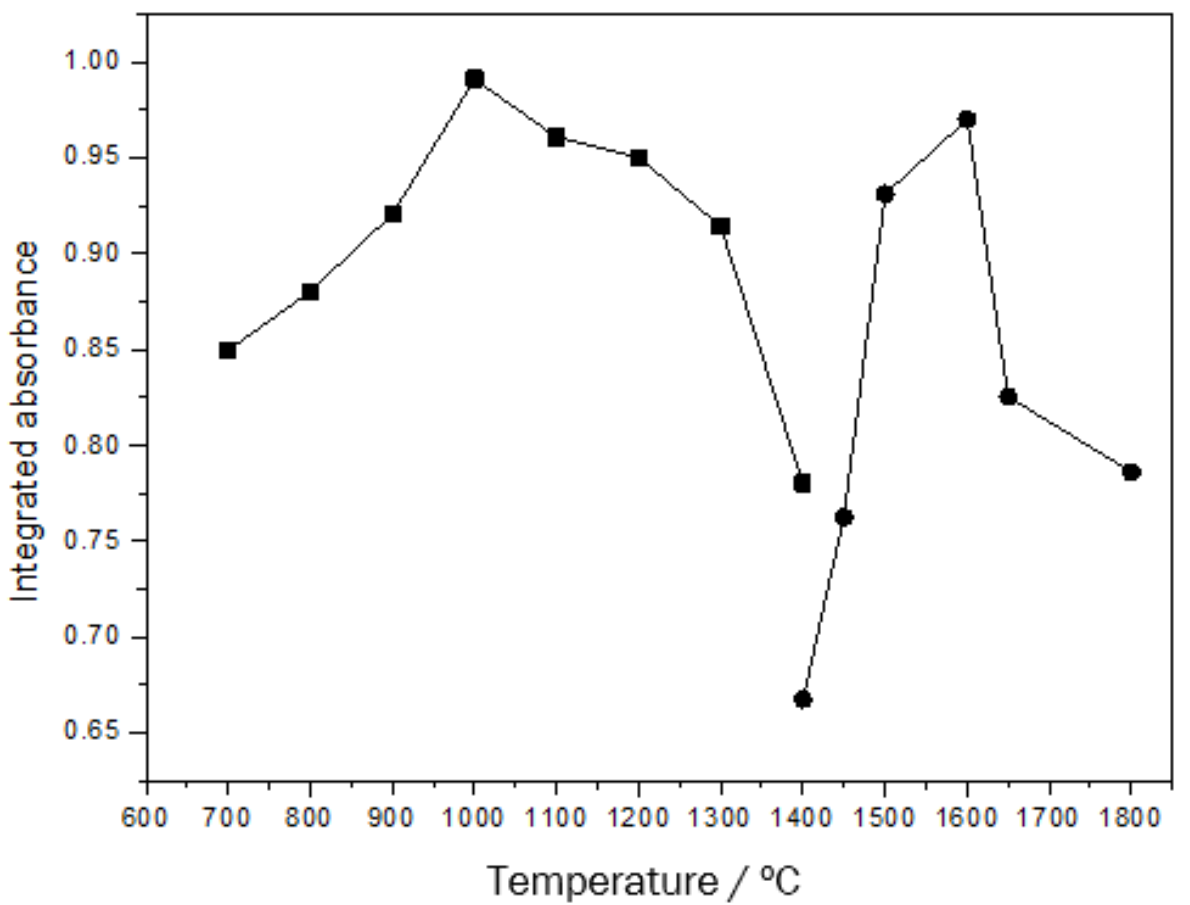

Figure 3. Pyrolysis ( $\bullet$ ) and atomization (•) temperature curves for $1.0 \mu \mathrm{g} \mathrm{L}^{-1} \mathrm{Zn}$ in the blank (absence of band gel) in $1.0 \%$ v/v $\mathrm{HNO}_{3}$ with $1.78 \%$ w/v $\mathrm{Mg}\left(\mathrm{NO}_{3}\right)_{2}$ of chemical modifiers.

It can be concluded that $\mathrm{Zn}$ is present in these samples in metal-binding proteins. There were no differences between the Zn-binding proteins' estimated values in UHT cow milk $(8.0 \pm 1.0 \%)$ and raw cow milk $(8.0 \pm 1.0 \%)$, which presented the highest $\mathrm{Zn}$ amount in 24 and $32 \mathrm{kDa}$, respectively. However, the largest proportion of $\mathrm{Zn}$ found in the $32 \mathrm{kDa}$ protein was in UHT cow milk $(17.0 \pm 2.0 \%)$ and $24 \mathrm{kDa}$ protein $(9.0 \pm 0.6 \%)$ in raw sheep milk. Studies were conducted to determine $\mathrm{Zn}$ bound to casein in breast milk, in which processed milk samples presented a change in the $\mathrm{Zn}$ distribution, with a decrease in the serum fraction and an increase in the fat fraction. There was no significant difference in the $\mathrm{Zn}$ percentage regarding casein. However, there was a trend towards increasing in processed samples ${ }^{30}$, as observed in this study. 
Previous studies ${ }^{9,19,31,32}$ showed that zinc could also be linked to the casein fraction, $\alpha$-casein and $\beta$-casein in bovine milk. The complex fractions of $\alpha$-k-casein and $\alpha-\beta$-casein showed significant zinc bound amounts, as can be demonstrated in this work.

Gaucheron et al. ${ }^{31}$ estimated that cations are bound to $\alpha$-casein and $\beta$-casein in the following affinity order: $\mathrm{Fe}>\mathrm{Zn}>\mathrm{Ca}$. Zinc was found with $3 \mathrm{CPP}$ (casein phosphopeptide) and the fraction containing $\alpha$-casein and the 3 CPPs containing amino acids (glutamic acid, serine and phosphoserine), showing the Zn-complexes formation ${ }^{23,32}$. Moreover, the $\mathrm{Zn}$ distribution between casein, whey and other components may be affected by $\mathrm{pH}$, heat and other cations present in the diet. Thus, the proteins are denatured and their ability to bind to $\mathrm{Zn}$ is probably reduced ${ }^{33-35}$. This reduction can be explained by the $\mathrm{Zn}$ percentage found in some proteins such as soybean $(52 \mathrm{kDa})$, raw cow $(24 \mathrm{kDa})$ and raw sheep (32 kDa).

Although contamination or species conversion problems cannot be ignored, gel electrophoresis is an important tool for the fractionation or separation of compounds, such as caseins, and $\mathrm{Zn}$ distribution can provide valuable information about the proteins' activity and their associated components.

\subsection{Determination of total protein}

Lipid extraction is not necessary during the Bradford method, so total protein determination was made directly in the diluted milk ${ }^{36}$. The aim was to observe if the ultra-high temperature (UHT) process caused changes in the milk total protein concentration when compared with the unprocessed samples. Results obtained for raw sheep, raw cow, UHT cow, UHT goat and soybean were $34 \pm 1 \mathrm{~g} \mathrm{~L}^{-1}, 21 \pm 1 \mathrm{~g} \mathrm{~L}^{-1}, 23 \pm 1 \mathrm{~g} \mathrm{~L}^{-}$ ${ }^{1}, 18 \pm 1 \mathrm{~g} \mathrm{~L}^{-1}$ and $16 \pm 1 \mathrm{~g} \mathrm{~L}^{-1}$, respectively. No significant difference was observed in the results that compared processed and not processed milk, in agreement with a previous work ${ }^{30}$.

Soybean is a protein supplier food composed by saturated and unsaturated fatty acids, vitamins and polyphenolic compounds, such as isoflavones ${ }^{35}$. It may be prepared to have the same protein content as bovine milk $^{34,35}$, which can be confirmed in this work $(16 \pm 1$ $\left.\mathrm{g} \mathrm{L}^{-1}\right)$. However, the biological value of soybean proteins is lower than bovine milk or eggs proteins ${ }^{35}$.

Proteins found in goat milk showed results comparable to bovine milk. The highest total protein concentration was found in sheep's milk, in agreement with the results reported by Raynal-Ljutovaca et al. ${ }^{24}$ and was similar to bovine milk.

\section{Conclusions}

This study evaluated a fractionation method for $\mathrm{Zn}$ proteins measurement in different milk samples by ETAAS. A method for total $\mathrm{Zn}$ quantification in different milk samples was also studied.

The $\mathrm{Zn}$ distribution results in protein bands were quantitative and could provide information about the relative $\mathrm{Zn}$ concentration in milk proteins. It was also possible to define the most appropriate polyacrylamide gels preparation procedure, the milk sample preparation and $\mathrm{Zn}$ determination. No differences were observed between the estimated values of $\mathrm{Zn}$-binding proteins in UHT cow milk and in raw cow milk, which presented the highest $\mathrm{Zn}$ concentrations in 24 and 32 $\mathrm{kDa}$, respectively. Total protein content in processed (UHT) and non-processed (raw) milk samples were also remarkably similar. The results showed that $\mathrm{Zn}$ is mainly bound to $32 \mathrm{kDa}$ ( $\beta$-casein) protein in UHT cow and $24 \mathrm{kDa}(\alpha$-casein) protein in raw sheep milk. The use of fractionation has been demonstrated as a complementary analytical tool for the characterization of $\mathrm{Zn}$ species present in milk.

\section{Acknowledgments}

This study was supported by the São Paulo Research Foundation (FAPESP, process 06/59537-0), CAPES (001) and Conselho Nacional de Desenvolvimento Científico e Tecnológico (CNPq, 409852/2018-0, 3091878/2018-1).

\section{References}

[1] Scheplyagina, L. A., Impact of the mother's zinc deficiency on the women's and newborn's health status, Journal of Trace Elements in Medicine and Biology 19 (1) (2005) 29-35. https://doi.org/10.1016/j.jtemb.2005.07.008.

[2] Ballard, O., Morrow, A. L. Human Milk Composition: Nutrients and Bioactive Factors, Pediatric Clinics of North $\begin{array}{lllll}\text { America } & 60 & \text { (1) } & \text { (2013) }\end{array}$ https://doi.org/10.1016/j.pcl.2012.10.002.

[3] Hodgkinson, A. J., Wallace, O. A. M., Smolenski, G., Prosser, C. G., Gastric digestion of cow and goat milk: Peptides derived from simulated conditions of infant digestion, Food Chemistry 276 (2019) 619-625. https://doi.org/10.1016/j.foodchem.2018.10.065.

[4] Michalke, B., Element speciation definitions, analytical methodology, and some examples, Ecotoxicology and Environmental Safety $56 \quad$ (1) (2003) 122-139. https://doi.org/10.1016/S0147-6513(03)00056-3. 
[5] Arruda, M. A. Z., Azevedo, R. A., Metallomics and chemical speciation: towards a better understanding of metal-induced stress in plants, Annals of Applied Biology 155 (2009) 301-307. https://doi.org/10.1111/j.17447348.2009.00371.x.

[6] Templeton, D. M., Ariese, F., Cornelis, R., Danielsson, L.-G., Muntau, H., van Leeuwen, H. P. V., Lobinski, R., Guidelines for terms related to chemical speciation and fractionation of elements. Definitions, structural aspects and methodological approaches (IUPAC Recommendations 2000), Pure and Applied Chemistry 72 (8) (2000) 14531470. https://doi.org/10.1351/pac200072081453.

[7] Shi, W., Chance, M. R., Metalloproteomics: forward and reverse approaches in metalloprotein structural and functional characterization, Current Opinion in Chemical Biology $\quad 15 \quad$ (1) (2011) 144-148. https://doi.org/10.1016/j.cbpa.2010.11.004.

[8] Dupont, D., Croguennec, T., Pochet, S., Milk Proteins Analytical Methods, Reference Module in Food Science (2018) 1-14. https://doi.org/10.1016/B978-0-08-1005965.22616-4.

[9] Pozzi, C. M. C., Braga, C. P., Vieira, J. C. S., Cavecci, B., Queiroz, J. V., Barbosa, H. S., Arruda, M. A. Z., Gozzo, F. C., Padilha, P. M., Metal ions bound to the human milk immunoglobulin A: Metalloproteomic approach, Food $\begin{array}{llll}\text { Chemistry } & 166 & \text { (2015) 492-497. }\end{array}$ https://doi.org/10.1016/j.foodchem.2014.06.040.

[10] Aslebagh, R., Channaveerappa, D., Arcaro, K. F., Darie, C. C., Comparative two dimensional polyacrylamide gel electrophoresis (2D-PAGE) of human milk to identify dysregulated proteins in breast cancer, Electrophoresis 39 (14) (2018) 1723-1734. https://doi.org/10.1002/elps.201800025.

[11] Vacchina, V., Oguey, S., Ionescu, C., Bravo, D., Lobinski, R., Characterization of metal glycinate complexes by electrospray Q-TOF-MS/MS and their determination by capillary electrophoresis-ICP-MS: application to premix samples, Analytical and Bioanalytical Chemistry 398 (2010) 435-449. https://doi.org/10.1007/s00216-010-3907-1.

[12] Santos, F. A., Lima, P. M., Neves, R. C. F., Moraes, P. M., Pérez, C. A., Silva, M. O. A., Arruda, M. A. Z., Castro, G. R., Padilha, P. M., Metallomic study on plasma samples from Nile tilapia using SR-XRF and GFAAS after separation by 2D PAGE: initial results, Microchimica Acta 173 (2011) 43-49. https://doi.org/10.1007/s00604-010-0522-y.

[13] Neves, R. C. F., Lima, P. M., Baldassini, W. A., Santos, F. A., Moraes, P. M., Castro, G. R., Padilha P. M., Fracionamento de cobre em proteínas do plasma, músculo e fígado de tilápia do Nilo. Química Nova 35 (3) (2012) 493498. https://doi.org/10.1590/S0100-40422012000300010.
[14] Wang, Q., Bernhard Michalke (Ed.): Metallomics: analytical techniques and speciation methods, Analytical and Bioanalytical Chemistry 409 (2017) 5617-5618. https://doi.org/10.1007/s00216-017-0524-2.

[15] Magalhães, C. S., Arruda, M. A. Z., Sample preparation for metalloprotein analysis: A case study using horse chestnuts, Talanta $71 \quad$ (5) (2007) 1958-1963. https://doi.org/10.1016/j.talanta.2006.08.039.

[16] Wang, Q., Xiong, Y. L., Zinc-binding behavior of hemp protein hydrolysates: Soluble versus insoluble zinc-peptide complexes, Journal of Functional Foods 49 (2018) 105-112. https://doi.org/10.1016/j.jff.2018.08.019.

[17] Silva, M. S., Sele, V., Sloth, J. J., Araujo, P., Amlund, H., Speciation of zinc in fish feed by size exclusion chromatography coupled to inductively coupled plasma mass spectrometry using fractional factorial design for method optimisation and mild extraction conditions, Journal of $\begin{array}{lllll}\text { Chromatography } & \text { B } & 1104 & \text { (2019) 262-268, }\end{array}$ https://doi.org/10.1016/j.jchromb.2018.11.010.

[18] Egito, A. S., Rosinha, G. M. S., Laguna, L. E., Miclo, L., Girardet, J. M., Gaillard, J. L., Método eletroforético rápido para detecção da adulteração do leite caprino com leite bovino, Arquivo Brasileiro de Medicina Veterinária e $\begin{array}{lllll}\text { Zootecnia } & 58 & \text { (5) } & \text { (2006) } & \text { 932-939. }\end{array}$ https://doi.org/10.1590/S0102-09352006000500032.

[19] Gomez, B. G., Perez-Corona, M. T., Madrid, Y., Availability of zinc from infant formula by in vitro methods (solubility and dialyzability) and size-exclusion chromatography coupled to inductively coupled plasmamass spectrometry, Journal of Dairy Science 99 (12) (2016) 9405-9414. https://doi.org/10.3168/jds.2016-11405.

[20] Liu, W., Lou, H., Ritzoulis, C., Chen, X., Shen, P., Lu, Y., Wu, K., Dong, L., Zhu, H., Han, J., Structural characterization of soybean milk particles during in vitro digestive/non-digestive simulation, LWT 108 (2019) 326331. https://doi.org/10.1016/j.lwt.2019.03.086.

[21] Maqsood, S., Al-Dowaila, A., Mudgil, P., Kamal, H., Jobe, B., Hassan, H. M., Comparative characterization of protein and lipid fractions from camel and cow milk, their functionality, antioxidant and antihypertensive properties upon simulated gastro-intestinal digestion, Food Chemistry 279 (2019) 328-338. https://doi.org/10.1016/j.foodchem.2018.12.011.

[22] Ren, C., Tang, L., Zhang, M., Guo, S., Interactions between whey soybean protein (WSP) and beta-conglycinin (7S) during the formation of protein particles at elevated temperatures, Food Hydrocolloids 23 (3) (2009) 936-941. https://doi.org/10.1016/j.foodhyd.2008.06.007.

[23] Naqvi, M. A., Irani, K. A., Katanishooshtari, M., Rousseau D., Disorder in Milk Proteins: Formation, 
Structure, Function, Isolation and Applications of Casein Phosphopeptides, Current Protein \& Peptide Science 17 (4) (2016) https://doi.org/10.2174/1389203717666151201191658.

[24] Raynal-Ljutovac, K., Lagriffoul, G., Paccard, P., Guillet, I., Chilliard, Y., Composition of goat and sheep milk products: An update, Small Ruminant Research 79 (1) (2008)

https://doi.org/10.1016/j.smallrumres.2008.07.009.

[25] Güler, Z., Levels of 24 minerals in local goat milk, its strained yoghurt and salted yoghurt (tuzlu yoğurt), Small $\begin{array}{lllll}\text { Ruminant Research } 71 \quad(1-3) \quad \text { (2007) } & 130 .\end{array}$ https://doi.org/10.1016/j.smallrumres.2006.05.011.

[26] Pereira Junior, J. B., Fernandes, K. G., Müller, R. C. S., Nóbrega, J. A., Palheta D. C., Determinação direta de Ca, $\mathrm{Mg}, \mathrm{Mn}$ e $\mathrm{Zn}$ em amostras de leite de búfala da ilha de marajó por espectrometria de absorção atômica com chama (FAAS) Química Nova 32 (9) (2009) 2333-2335. https://doi.org/10.1590/S0100-40422009000900018.

[27] Bossu, C. M., Carioni, V. M. O., Naozuka, J., Oliveira, P. V., Nomura, C. S., Direct determination of arsenobetaine and total As in robalo fish liver and tuna fish candidate reference material by slurry sampling graphite furnace atomic absorption spectrometry (SLS-GF AAS), Eclética Química Journal $44 \quad$ (2) (2019) 37-44. https://doi.org/10.26850/1678-4618eqj.v44.2.2019.p37-44.

[28] Taverniers, I., Loose, M., Van Bockstaele, E., Trends in quality in the analytical laboratory. II. Analytical method validation and quality assurance, TrAC Trends in Analytical $\begin{array}{lllll}\text { Chemistry } & 23 & \text { (8) } & \text { (2004) 535-552. }\end{array}$ https://doi.org/10.1016/j.trac.2004.04.001.

[29] Chudzinka, M., Debska, A., Baralkiewicz, D., Method validation for determination of 13 elements in honey samples by ICP-MS, Accreditation and Quality Assurance 17 (2012) 65-73, https://doi.org/10.1007/s00769-011-0812$\mathrm{Z}$.

[30] Góes, H. C. A., Torrese, A. G., Donangelo, C. M., Trugo, N. M. F., Nutrient composition of banked human milk in Brazil and influence of processing on zinc distribution in milk fractions, Nutrition 18 (7-8) (2002) 590594. https://doi.org/10.1016/S0899-9007(02)00813-4.

[31] Gaucheron, F., The minerals of milk, Reproduction Nutrition Development 45 (4) (2005) 473-483. https://doi.org/10.1051/rnd:2005030.

[32] Miquel, E., Farré, R., Effects and future trends of casein phosphopeptides on zinc bioavailability, Trends in Food Science \& Technology 18 (3) (2007) 139-143. https://doi.org/10.1016/j.tifs.2006.11.004.
[33] Pabón, M. L., Lönnerdal, B., Bioavailability of zinc and its binding to casein in milks and formulas, Journal of Trace Elements in Medicine and Biology 14 (3) (2000) 146-153. https://doi.org/10.1016/S0946-672X(00)80003-6.

[34] Jung, S., Murphy, P. A., Sala I., Isoflavone profiles of soymilk as affected by high-pressure treatments of soymilk and soybeans, Food Chemistry 111 (3) (2008) 592-598. https://doi.org/10.1016/j.foodchem.2008.04.025.

[35] Zaheer, K., Akhtar, M. H. An updated review of dietary isoflavones: Nutrition, processing, bioavailability and impacts on human health. Journal Critical Reviews in Food Science and Nutrition 57 (6) (2017) 1280-1293. https://doi.org/10.1080/10408398.2014.989958.

[36] Kamizake, N. K. K., Gonçalves, M. M., Zaia, C. T. B. V., Zaia, D. A. M., Determination of total proteins in cow milk powder samples: a comparative study between the Kjeldahl method and spectrophotometric methods, Journal of Food Composition and Analysis 16 (4) (2003) 507-516. https://doi.org/10.1016/S0889-1575(03)00004-8. 